\title{
КРИМІНАЛЬНО-ПРАВОВА ТА КРИМІНОЛОГІЧНА ХАРАКТЕРИСТИКА ЛЕГАЛІЗАЦІЇ (ВІДМИВАННЯ) ДОХОДІВ, ОДЕРЖАНИХ ЗЛОЧИННИМ ШЛЯХОМ
}

Легалізація (відмивання) доходів, одержаних злочинним шляхом на сьогодні $€$ одним із основних напрямків діяльності організованих злочинних угрупувань і злочинних організацій, що має транснаціональний характер i тягне за собою спричинення тяжких наслідків для економіки більшості держав світової спільноти. Не підлягає сумніву той факт, що легалізація злочинних доходів стала глобальною загрозою економічній і політичній безпеці, у зв'язку з чим цей вид злочинної діяльності перебуває в центрі уваги правоохоронних і фінансових органів, які, у свою чергу, потребують прийняття узгоджених заходів щодо протидіï цьому явищу як на національному, так і на міжнародному рівнях.

Результати теоретичних досліджень та практичного досвіду, пов'язаних з протидією легалізації (відмиванню) доходів, одержаних злочинним шляхом, опубліковані у працях таких вчених та практиків, як П. П. Андрушко, Л. І. Аркуша, С. Н. Баліна, О. М. Бандурка, В. П. Головіна, М. В. Джига, О. Ф. Долженков, Л. М. Доля, О. О. Дудоров, В. А. Журавель, Н. С. Карпов, Я. Ю. Кондратьєв, О. Є. Користін, Н. М. Мироненко, С. І. Ніколаюк, Д. Й. Никифорчук, В. М. Попович, Г. М. Потинка, А. М. Решелюк, О. Б. Сахарова, А. Г. Семчук, М. С. Хруппа, В. Ю. Шепитько та інші. Оцінюючи наукові здобутки даної проблематики, слід зауважити, що питання протидії легалізації (відмиванню) доходів, отриманих злочинним шляхом, розроблені не остаточно та потребують подальших досліджень.
У цій сфері залишається значне коло питань, поки що не розв'язаних.

Метою статті є розгляд проблем протидії легалізації (відмивання) доходів, одержаних злочинним шляхом.

Суспільна небезпека легалізації (відмивання) доходів, одержаних злочинним шляхом полягає у заподіянні шкоди легальній економічній діяльності, створенні матеріального підгрунтя для збільшення масштабів злочинної діяльності, дестабілізації нормального функціонування фінансової системи, зниженні рівня довіри до неї, посиленні інфляційних процесів, порушенні принципу рівноправності суб'єктів підприємницької діяльності, посиленні недобросовісної конкуренції та майнового розшарування суспільства, погіршенні міжнародного іміджу України.

Легалізація (відмивання) доходів, одержаних злочинним шляхом, є типовим конвенційним злочином, тобто діянням, криміналізація якого відбулась у зв'язку з вступом нашої держави до числа учасників відповідних міжнародно-правових актів.

Основним безпосереднім об'єктом злочину $€$ встановлений, 3 метою протидіï залученню в економіку «брудних» коштів, порядок здійснення господарської діяльності, а також порядок вчинення цивільно-правових правочинів у частині використання майна, не пов'язаного з господарською діяльністю. Додатковими об'єктами злочину виступають інтереси правосуддя, фінансова система, засади добросовісної конкуренції.

Предмет злочину - кошти та інше майно, одержане внаслідок вчинення 
суспільно небезпечного протиправного діяння, що передувало легалізації (відмиванню) доходів (предикатне діяння).

Кошти та інше майно виступають предметом легалізації за умови, що їх одержання відбулося заздалегідь і було поєднано з порушенням норм тільки кримінального законодавства України або іншої держави. Це випливає 3 назви ст. 209 Кримінального кодексу України (далі - КК України), де прямо вказується на доходи, одержані саме злочинним шляхом [1].

Слід зазначити, що законодавче визначення предикатного діяння неодноразово зазнавало змін.

Зокрема, за ст. 209 КK України у редакції Закону України від 5 квітня 2001 р. № 2341-III предметом легалізації визнавались грошові кошти та інше майно, здобуті злочинним шляхом [2].

За ст. 209 КК України в редакції Закону України від 16 січня 2003 р. № 430-IV предикатним діянням визнавалось: по-перше, діяння, за яке KK України передбачено покарання у виді позбавлення волі на строк від трьох і більше років (за винятком діянь, передбачених ст. ст. 207, 212 КК України); по-друге, діяння, яке визнається злочином за кримінальним законом іншої держави і за таке саме діяння передбачена відповідальність КK України [3]. Другий вид діянь у судовій практиці мав обмежувальне тлумачення як діяння, яке визнається злочином згідно з кримінальним законодавством іншої держави, якщо й КК України за таке саме діяння передбачена кримінальна відповідальність у виді позбавлення волі на строк не менше трьох років (п. 1 Постанови Пленуму Верховного Суду України «Про практику застосування судами законодавства про кримінальну відповідальність за легалізацію (відмивання) доходів, одержаних злочинним шляхом» від 15 квітня 2005 р. № 5 [4].У п. 1 примітки до ст. 209 КК України в редакції Закону України від 18 травня 2010 р. № 2258VI обидва види предикатних діянь були сфрормульовані по новому: по-перше, це діяння, за яке КK України передбачено покарання у виді позбавлення волі (за винятком діянь, передбачених ст. ст. 207, 212 та 212-1 KK України); по-друге, це діяння, вчинене за межами України, якщо воно визнається суспільно небезпечним протиправним діянням, що передувало легалізації (відмиванню) доходів, за кримінальним законом держави, де воно було вчинене, і є злочином за КК України [5].

У п. 1 примітки до ст. 209 KK України в редакції Закону України від 15 листопада 2011 р. № 4025-VI зазначено такі два види предикатних діянь: по-перше, це діяння, за яке КK України передбачено основне покарання у виді позбавлення волі або штрафу понад три тисячі неоподаткованих мінімумів доходів громадян (за винятком діянь, передбачених ст. ст. 212 і 212-1 KK України); по-друге, це діяння, вчинене за межами України, якщо воно визнається суспільно небезпечним протиправним діянням, що передувало легалізаціі (відмиванню) доходів, за кримінальним законом держави, де воно було вчинене, і є злочином за KK України [6].

На сьогодні п. 1 примітки до ст. 209 КК України діє в редакціï Закону України від 14 жовтня 2014 року № 1702-VII та виділяє такі два види предикатних діянь: по-перше, це діяння, за яке KK України передбачено основне покарання у виді позбавлення волі або штрафу понад три тисячі неоподаткованих мінімумів доходів громадян; по-друге, це діяння, вчинене за межами України, якщо воно визнається суспільно небезпечним протиправним діянням, що передувало легалізації (відмиванню) доходів, за кримінальним законом держави, де воно було вчинене, і є злочином за КK України та внаслідок вчинення якого незаконно одержані доходи [7].

Відповідальність за ст. 209 КК Украіни не виключена i у тих випадках, коли особа, яка вчинила предикатне діяння, була звільнена від кримінальної відповідальності у встановленому зако- 


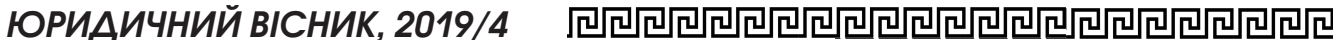

ном порядку (у зв’язку із закінченням строків давності, застосуванням акта амністії тощо) або не притягувалася до такої відповідальності (наприклад, у зв'язку зі смертю), а одержані внаслідок зазначеного діяння кошти або інше майно стали предметом легалізації.

Кваліфікація за ст. 209 КК України можлива і тоді, коли особа не притягувалась до кримінальної відповідальності за предикатне діяння. У такому випадку особа одночасно притягується до кримінальної відповідальності за предикатний злочин та за легалізацію (відмивання) коштів або іншого майна, одержаних унаслідок його вчинення, тобто за сукупністю цих злочинів, оскільки вона усвідомлює, що вчиняє легалізацію таких коштів (майна).

Для кваліфікації за ст. 209 КK України не має значення місце вчинення суспільно небезпечного протиправного діяння, що передувало легалізації (відмиванню) доходів, тобто місцем одержання «брудних» доходів може бути територія як України, так і іноземної держави. В останньому випадку вимагається, щоб діяння - джерело доходів одночасно визнавалось і предикатним злочином за кримінальним законом іноземної держави, і злочином, внаслідок вчинення якого одержуються доходи, за КК України.

Буквальне тлумачення примітки до ст. 209 КК України дає змогу дійти висновку про те, що вчинене за кордоном суспільно небезпечне протиправне діяння, яке передувало легалізації (відмиванню) доходів, не обов'язково має тягнути основне покарання у вигляді позбавлення волі або штрафу понад три тисячі неоподаткованих мінімумів доходів громадян. Для визнання предикатним діянням злочину, вчиненого в іншій державі, не має значення, яке за видом та розміром покарання передбачене за його вчинення як іï кримінальним законом, так і за таке саме діяння КK України у разі його вчинення на території України.

Стосовно вчинених в Україні суспільно небезпечних протиправних діянь, що передували легалізації (відмиванню) доходів, то у чинній редакції ст. 209 КК України реалізовано ідею обмеження кола діянь як джерела «брудних» доходів. Зокрема, 3 кола предикатних виключені діяння, за які згідно з КК України передбачено основне покарання, менш суворе, ніж позбавлення волі або штрафу, розмір якого дорівнює або є меншим, ніж три тисячі неоподаткованих мінімумів доходів громадян.

Конкретний злочинний спосіб, за допомогою якого одержано майно предмет розглядуваного злочину, на кваліфікацію за ст. 209 КК України не впливає (за винятком вказаних вище обмежень). Це може бути той чи інший злочин проти власності, одержання хабара, вбивство з корисливих мотивів, незаконне виготовлення підакцизних товарів тощо.

Не $€$ предметом легалізації кошти (незалежно від іх розміру), одержані як субсидії, субвенції, дотації чи кредити внаслідок надання неправдивої інформації, хоча з такими коштами надалі і вчинюються діяння, перелічені у ст. 209 КК України, оскільки ці кошти одержуються офіційно (легально) і злочин, передбачений ст. 222 KK України, не містить усіх ознак предикатного діяння, визначеного у п. 1 примітки до ст. 209 КК України [1].

Використання коштів, здобутих від незаконного обігу наркотичних засобів, психотропних речовин, їх аналогів, прекурсорів, отруйних чи сильнодіючих речовин або отруйних чи сильнодіючих лікарських засобів, за загальним правилом, потрібно кваліфікувати за спеціальною кримінально-правовою нормою (ст. 306 КК України) [1]. При цьому, якщо за ці кошти придбається майно, яке не підлягає приватизації або яке не належить до обладнання для виробничих та інших потреб (наприклад, нерухомість або транспортний засіб), або ж такі кошти використовуються у правомірній підприємницькій та іншій господарській діяльності, але не у вигляді розміщення їх у банках, 
на підприємствах, в установах, організаціях та їх підрозділах, вчинене треба кваліфікувати не за ст. 306, а за ст. 209 КК України (за наявності всіх ознак складу злочину).

Об'єктивна сторона злочину, передбаченого ст. 209 KK України може альтернативно виражатись в одній з чотирьох форм: 1) вчинення фінансової операції 3 коштами або іншим майном, одержаними внаслідок вчинення суспільно небезпечного протиправного діяння, що передувало легалізації (відмиванню) доходів; 2) вчинення правочину 3 такими коштами та майном; 3) вчинення дій, спрямованих на приховання чи маскування незаконного походження таких коштів або майна чи володіння ними, прав на такі кошти або майно, джерела їх походження, місцезнаходження або переміщення; 4) набуття, володіння або використання коштів чи іншого майна, одержаних унаслідок вчинення суспільно небезпечного протиправного діяння, що передувало легалізації (відмиванню) доходів.

Відповідно до чинного закону суб'єктом легалізації (відмивання) доходів, одержаних злочинним шляхом, тобто злочину, передбаченого ст. 209 KK України, є фізична осудна або обмежено осудна особа, яка досягла на момент вчинення вказаного злочину 16-ти років (ч. 1 ст. 22 КК України) [1].

Суб'єктом цього злочину може бути як приватна, так і службова особа. За ст. 209 КК України може нести відповідальність як особа, яка вчинила суспільно небезпечне протиправне діяння, що передувало легалізації (відмиванню) доходів, і наступні дії, які охоплюються поняттям легалізації, так і той, хто не вчиняв предикатного діяння. Викладена точка зору виходить з того, що чинний KK України не розглядає легалізацію (відмивання) доходів, одержаних злочинним шляхом як форму причетності до предикатного злочину.

Вчинення злочину, передбаченого ст. 209 КК України службовою особою 3 використанням свого службового становища в усякому разі потребує додаткової кваліфікації дій цієї особи в залежності від конкретних обставин: за ст. 364 KK України (зловживання владою або службовим становищем); за ст. 365 KK України (перевищення влади або службових повноважень); за ст. 366 КК України (службове підроблення) [1].

Слід також відзначити, що суб'єктом досліджуваного злочину, якщо він вчиняється службовою особою, може бути не кожна фізична осудна або обмежено осудна особа, що вчинила злочин у віці, з якого законом передбачено настання кримінальної відповідальності (16 років). Крім цього, потрібно, щоб злочинні дії вказаної особи відбувались iз використанням легально встановленого механізму господарських відносин, бо тільки так вона може посягнути на встановлений законом порядок господарювання в Україні - об’єкт злочину, передбаченого ст. 209 KK України. Тому слід встановити - чи має ця особа право виступати певним учасником (суб'єктом, або представляти суб'єкт) господарських відносин. 3 цією метою необхідно уважно вивчити документи, що підтверджують дієздатність та/або спеціальну правосуб'єктність вказаної особи.

Таким чином, суб'єкт цього злочину повинен мати компетенцію учасника відносин у сфері господарювання. До цієї категорії, згідно з ч. 1 ст. 2 Господарського кодексу України належать такі: 1) суб'єкти господарювання; 2) споживачі; 3) органи державної влади та органи місцевого самоврядування, наділені господарською компетенцією; 4) громадяни, громадські та інші організації, які виступають засновниками суб'єктів господарювання чи здійснюють щодо них організаційно-господарські повноваження на основі відносин власності [8]. До того ж, як справедливо підкреслено у п. 15 Постанови Пленуму Верховного Суду України № 5 від 15.04.2005 року «Про практику застосування судами законодавства про кримінальну відповідальність за легалізацію 


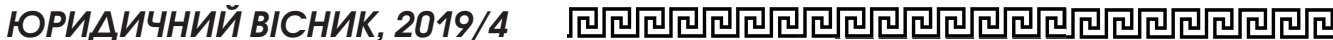

(відмивання) доходів, одержаних злочинним шляхом», суб'єктом злочину, склад якого передбачено в ст. 209 KK України, може бути не просто фізична осудна або обмежено осудна особа, яка досягла 16-річного віку, а стосовно вчинення тих чи інших правочинів, ще й набула повної дієздатності у випадках та порядку, передбачених законом, і не була обмежена у дієздатності або не позбавлена іï судом [4].

Суб'єктивна сторона злочину, передбаченого ст. 209 KK України характеризується прямим умислом. Для кваліфікації за ст. 209 КК України не вимагається точної обізнаності про характер та конкретні обставини вчинення предикатного діяння, але необхідним є усвідомлення особою тих фактичних обставин вчиненого, з якими КK України пов'язує можливість призначення основного покарання у вигляді позбавлення волі або штрафу понад три тисячі неоподатковуваних мінімумів доходів громадян. Обізнаність особи про відповідне походження «брудного» майна встановлюється у кожному конкретному випадку.

Найменування розглядуваного злочину, а також звернення до положень законодавства про протидію легалізації (відмиванню) доходів, одержаних злочинним шляхом дають змогу дійти висновку про те, що у ст. 209 КК України йдеться про таке залучення відповідного майна у побутовий і господарський обіг, яке поєднується 3 прагненням надати цьому процесу правомірний вигляд. Таке прагнення може поєднуватись із задоволенням власних потреб чи мотивів винної особи (наприклад, 3 бажанням отримати прибуток або допомогти тому, хто вчинив предикатне діяння, уникнути покарання за скоєне). Для кваліфікації за ст. 209 КК України потрібно встановити, що дії винного були вчинені умисно і з метою надання правомірного вигляду володінню, використанню, розпорядженню відповідними коштами або майном, їх набуттю чи для приховання джерел їхнього походження. Тобто бажання приховати справжнє джерело майна, щодо якого вчиняються правочини, інші дії або яке використовується, і видати «брудне» майно за легальні доходи виступає як обов'язкова характеристика суб'єктивної сторони. Через відсутність такого бажання випадки використання «брудного» майна для продовження вчинення незаконних, у тому числі кримінально караних діянь (наприклад, для незаконного виготовлення підакцизних товарів) не утворюють складу злочину, передбаченого ст. 209 КК України.

Українське законодавство характеризує відмивання доходів, одержаних злочинним шляхом, органічно поєднуючи його з визначенням Міжнародних $\mathrm{KoH}_{-}$ венцій ООН, в яких зазначається, що злочини вчиняються 3 використанням фінансових операцій чи укладення угод 3 коштами або іншим майном, одержаних внаслідок вчинення суспільно небезпечного протиправного діяння, що передувало такій легалізаціі. Тому, однією з обов'язкових ознак предмета «відмивання» $€$ злочинне походження таких коштів. У той самий час мета легалізації (відмивання) доходів, одержаних злочинним шляхом, є критерієм, відповідно до якого цей злочин треба відмежовувати від схожих діянь, передбачених іншими нормами кримінального права.

У статті розглянуто питання легалізації (відмивання) доходів, одернаних злочинним шляхом у теоретичному та правовому аспектах. Досліджено кримінально-правову та кримінологічну характеристику цього виду протиправної діяльності, зокрема, об'єкт та предмет злочину, зміни законодавчого визначення предикатного діяння, об'єктивну та суб'єктивну сторони, особливості суб'єкта злочину. Встановлено, що суспільна небезпека легалізації (відмивання) доходів, одержаних злочинним шляхом полягае у заподіянні шкоди легальній економінній діяльності, створенні матеріального підгрунтя для збільшення масштабів злочинної діяльності, дестабілізації нормального функціонування 
фінансової системи, зниженні рівня довіри до неї, посиленні інфляційних процесів, порушенні принципу рівноправності суб'єктів підприємницької діяльності, посиленні недобросовісної конкуренцї та майнового розшарування суспільства, погіршенні міжнародного іміджу України. Легалізація злочинних доходів стала глобальною загрозою економічній $i$ політичній безпеці, у зв'язку з чим цей вид злочинної діяльності перебуває в центрі уваги правоохоронних $i$ фінансових органів, які, у свою чергу, потребують прийняття узгоджених заходів щзодо протидіi цььому явищу як на національному, так $i$ на міннародному рівнях. Легалізація є типовим конвениійним злочином, тобто діянням, криміналізація якого відбулась у зв'язку з вступом нашої держави до числа учасників відповідних міжнародно-правових актів. Зроблено висновок, що досліджуваний злочин вчиняється з використанням фінансових операцій чи укладення угод з коштами або іншим майном, одержаними внаслідок вчинення суспільно небезпечного протиправного діяння, що передувало такій легалізациї, а мета легалізації, є критерієм, відповідно до якого ией злочин треба відмежовувати від схожих діянь, передбачених іншими нормами кримінального права. Створення в Україні сучасної нормативної бази боротьби з відмиванням доходів, одержаних злочинним шляхом, є важливим $i$ актуальним завданням.

Ключові слова: злочинні кошти, злочинні доходи, легалізація злочинних доходів, правове забезпечення, кримінально-правова та кримінологічна характеристика.

Frolov S. CRIMINAL-LEGAL ANDCRIMINOLOGICALCHARACTERISTICS OF LEGALIZATION (WASHING) OF MONEY RECEIVED BY A CRIMINAL WAY

The article deals with the issue of legalization (laundering) of proceeds of crime in theoretical and legal aspects. The criminal law and criminological characteristics of this type of illegal activity, in particular, the object and object of the crime, changes in the legislative definition of predicate act, objective and subjective parties, peculiarities of the subject of the crime are investigated. It is established that the public danger of legalization (laundering) of proceeds of crime is to cause damage to legal economic activity, to create a material basis for increasing the scale of criminal activity, destabilizing the normal functioning of the financial system, reducing the level of trust in it, and strengthening business entities, increased unfair competition and property stratification of society, deterioration of international Ukraine's image. The legalization of criminal proceeds has become a global threat to economic and political security, and this is why this type of criminal activity is the focus of law enforcement and financial authorities, which in turn require concerted action to counter this phenomenon both nationally and at the international level. Legalization is a typical convention crime, that is, an act whose criminalization occurred in connection with the accession of our country to the number of participants in the relevant international legal acts. It is concluded that the investigated crime is committed using financial transactions or entering into agreements with funds or other property obtained as a result of committing a socially dangerous unlawful act, which preceded such legalization, and the purpose of legalization is the criterion according to which this crime must be distinguished provided for by other rules of criminal law. Creating a modern regulatory framework for combating money laundering in Ukraine is an important and urgent task.

Key words: criminal means, criminal proceeds, legalization of criminal proceeds, legal support, criminal law and criminological characteristics. 


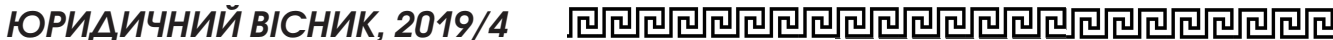

Література

1. Кримінальний кодекс України : Закон від 05 квіт. 2001 р. № 2341III. URL: https://zakon5.rada.gov.ua/ laws/show/2341-14 (дата звернення: 19.11.2019)

2. Кримінальний кодекс України : Закон України від 5 квіт. 2001 р. № 2341-III. Відомості Верховної Ради України. 2001 № 25-26. C. 131 .

3. Про внесення змін до Кримінального та Кримінально-процесуального кодексів України : Закон України від 16 січ. 2003 р. № 430-IV. Голос України. 2003. № 26.11 лют.

4. Про практику застосування судами законодавства про кримінальну відповідальність за легалізацію (відмивання) доходів, одержаних злочинним иляхом : Постанова Пленуму Верховного Суду України від 15 квіт. 2005 р. № 5. Відомості Верховного Суду України. 2005. № 5. C. 9 .
5. Про внесення змін до Закону України «Про запобігання та протидію легалізаиіi (відмиванню) доходів, одержаних злочинним шляхом»: Закон України від 18 травн. 2010 р. № 2258-VI. Відомості Верховної Ради України. 2010. № 29. С. 392.

6. Про внесення змін до деяких законодавчих актів України щодо гуманізації відповідальності за правопорушення у сфері господарської діяльності : Закон України від 15 rucmon. 2011 p. № 4025-VI. Голос України. 2011. № 239. 17 груд.

7. Про запобігання та протидію легалізації (відмиванню) доходів, одержаних злочинним шляхом, фінансуванню тероризму та фінансуванню розповсюдження зброї масового знищення : Закон від 14 жовт. 2014 p. № 1702-VII. URL: https://zakon. rada.gov.ua/laws/main/1702-18 (Jama звернення: 19.11.2019).

8. Господарський кодекс України: Закон від 16 січ. 2003 р. № 436-IV. URL: https: / / zakon.rada.gov.ua/laws / main/436-15 (дата звернення: 19.11.2019). 